\title{
Siew New Disease Reports \\ First report of Maize yellow mosaic virus infecting maize in Burkina Faso
}

\author{
E. Palanga ${ }^{1,2}{ }^{2}$, R.D.S. Longué ${ }^{1}$, M. Koala ${ }^{1}$, J.B. Néya ${ }^{1}$, O. Traoré ${ }^{1}$, D.P. Martin ${ }^{3}$, M. Peterschmitt ${ }^{2}$, D. Filloux ${ }^{2}$ and P. \\ Roumagnac $^{2}$ \\ ${ }^{1}$ INERA/Laboratoire de Virologie et de Biotechnologies Végétales/LMI-Patho bios, 01 BP 476 Ouagadougou 01, Burkina \\ Faso; ${ }^{2}$ CIRAD-INRA-Montpellier SupAgro, UMR BGPI, Campus International de Baillarguet, 34398 Montpellier, France; ${ }^{3}$ \\ Computational Biology Group, Institute of Infectious Disease and Molecular Medicine, Faculty of Health Sciences, University \\ of Cape Town, Observatory 7925. South Africa
}

*E-mail: patrick04pep@yahoo.fr

Received: 19 Mar 2017. Published: 11 May 2017.

Maize yellow mosaic virus (MaYMV) is a new polerovirus discovered recently in China in maize (Zea mays) displaying foliar yellowing and mosaic (Chen et al., 2016). Interestingly, a few months later, MaYMV was reported from Ecuador in maize (A. Bernreiter, pers. comm) and Nigeria in sugarcane and itch grass (Yahaya et al., 2017), suggesting that this new polerovirus is broadly distributed and is potentially emerging worldwide.

In August-September 2016, during a sampling survey carried out by the Agricultural Research Centre of Kamboinsé (ARCK, Burkina Faso), maize leaves showing yellow stripes, yellowing and yellow mosaic symptoms (Figs. 1-3) were collected from five fields surrounding ARCK, from which 15 to $20 \%$ of the plants appeared diseased. Leaves of fourteen diseased plants were tested by RT-PCR for the presence of poleroviruses using generic detection primers (PoleroNB3897F/PoleroNB4160R) as described by Palanga et al. (2016) and five MaYMV-specific detection primer pairs (vsi-F2/vsi-R2, vsi-F1/R1, MaYMV-F/MaYMV-R, F1/R1 and F1/vsi-R3) as described by Chen et al. (2016). Seven of the fourteen samples (MaYMV-BF6, MaYMV-BF7, MaYMV-BF8, MaYMV-BF9, MaYMVBF11, MaYMV-BF14 and MaYMV-BF16) tested positive using all six primer pairs. Amplicons of 263 to $2700 \mathrm{bp}$ generated using these six primer pairs were sequenced using the Sanger method (Genewiz, USA). The sequences were assembled, aligned and trimmed using DNA Baser V4 (Heracle BioSoft S.R.L., Romania) to give consensus sequences of $1763 \mathrm{nt}$. These sequences covered the open reading frames coding the coat protein (CP), the movement protein, the P3a protein and part of the RdRp. Pairwise identities between the consensus sequences obtained from the seven samples (GenBank Accession Nos. KY711382-KY711388) and polerovirus sequences from GenBank were determined using SDT v1.2 (Muhire et al., 2014). The seven consensus sequences from Burkina Faso shared $98-98.7 \%$ identity with the Chinese MaYMV isolates. Moreover, nucleotide identities between the Burkina Faso isolates were 99-100\%. A neighbour-joining phylogenetic tree was inferred (MEGA6; Tamura et al., 2013) from the CP amino acid sequences of the seven Burkina Faso isolates, the MaYMV CP sequences from China and Ecuador and eight other representative polerovirus and luteovirus CP sequences (Fig. 4). Sequences from the Burkina Faso isolates clearly cluster with MaYMV CP sequences from China and Ecuador.

Altogether, these results support the conclusion that MaYMV is present in Burkina Faso, indicating a global distribution of this recently discovered virus including Africa, Asia and South America.

\section{Acknowledgements}

We acknowledge LMI Patho-Bios which facilitated the preliminary RTPCR identification and CIRAD, Montpellier which supported the sequencing.

\section{References}

Chen S, Jiang G, Wu J, Liu Y, Qian Y, Zhou X, 2016. Characterization of a novel polerovirus infecting maize in China. Viruses 8, 1-17. http://dx.doi.org/10.3390/v8050120

Muhire BM, Varsani A, Martin DP, 2014. SDT: a virus classification tool based on pairwise sequence alignment and identity calculation. PLoS One 26, e108277. http://dx.doi.org/10.1371/journal.pone. 0108277

Palanga E, Filloux D, Martin DP, Fernandez E, Gargani D, Ferdinand R, Zabré J, Bouda Z, Bouma Neya J, Sawadogo M, Traore O, Peterschmitt M, Roumagnac P, 2016. Metagenomic-based screening and molecular characterization of cowpea-infecting viruses in Burkina Faso. Plos One 11, e0165188. http://dx.doi.org/10.1371/journal.pone. 0165188

Tamura K, Stecher G, Peterson D, Filipski A, Kumar S, 2013. MEGA6: Molecular Evolutionary Genetics Analysis version 6.0. Molecular Biology and Evolution 30, 2725-2729. http://dx.doi.org/10.1093/molbev/mst197

Yahaya A, Al Rwahnih M, Dangora DB, Gregg L, Alegbejo MD, Lava Kumar P, Alabi OJ, 2017. First report of Maize yellow mosaic virus infecting sugarcane (Saccharum spp.) and itch grass (Rottboellia cochinchinensis) in Nigeria. Plant Disease (in press). http://dx.doi.org/10.1094/PDIS-03-17-0315-PDN

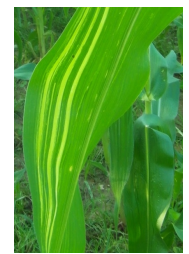

Figure 1

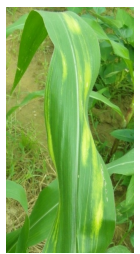

Figure 2

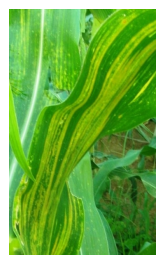

Figure 3

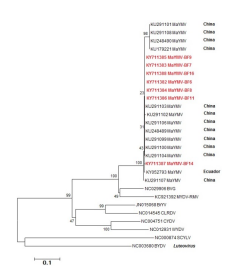

Figure 4

To cite this report: Palanga E, Longué RDS, Koala M, Néya JB, Traoré O, Martin DP, Peterschmitt M, Filloux D, Roumagnac P, 2017. First report of Maize yellow mosaic virus infecting maize in Burkina Faso. New Disease Reports 35, 26. http://dx.doi.org/10.5197/j.2044-0588.2017.035.026 